\title{
Effect of low temperature culture on the biological characteristics and aggressiveness of Sclerotinia sclerotiorum and Sclerotinia minor
}

\author{
Ruifang Jia, Min Li, Jian Zhang, Mandela E. Addrah and Jun Zhao* \\ College of Horticulture and Plant Protection, Inner Mongolia Agricultural University, Hohhot, People's Republic of China (PRC)
}

Received 17 May 2020 - Accepted 6 January 2021

\begin{abstract}
Sunflower White Mold caused by Sclerotinia sclerotiorum and Sclerotinia minor is a devastating disease worldwide. To investigate the effect of low temperature $\left(4^{\circ} \mathrm{C}\right)$ on biological characteristics and aggressiveness of isolates of the two species, which were collected from the same field in Baiyinchagan, Inner Mongolia, their mycelial growth rate, oxalic acid secretion level and polygalacturonase activity were compared under normal culture temperature $\left(23^{\circ} \mathrm{C}\right)$ and low temperature $\left(4{ }^{\circ} \mathrm{C}\right)$. Aggressiveness was also evaluated on detached leaves by inoculating the isolates produced in both temperatures. The results suggested that culture of isolates at $4{ }^{\circ} \mathrm{C}$ not only promoted mycelial growth, but also enhanced secretion of oxalic acid and polygalacturonase activity of both $S$. sclerotiorum and S. minor isolates compared to that cultured at $23{ }^{\circ} \mathrm{C}$. Additionally, the corresponding aggressiveness of tested isolates of the two species also increased after culture at $4^{\circ} \mathrm{C}$. However, S. sclerotiorum always showed faster mycelial growth, higher oxalic acid levels and greater polygalacturonase activity than $S$. minor at both $23^{\circ} \mathrm{C}$ and $4{ }^{\circ} \mathrm{C}$, indicating that $S$. sclerotiorum is generally the more aggressive species than $S$. minor.
\end{abstract}

Keywords: Sclerotinia sclerotiorum / Sclerotinia minor / low temperature culture / biological characteristics / aggressiveness /

\begin{abstract}
Résumé - Effet d'une culture à basse température sur les caractéristiques biologiques et l'agressivité de Sclerotinia sclerotiorum et Sclerotinia minor. La pourriture blanche du tournesol causée par Sclerotinia sclerotiorum et Sclerotinia minor est une maladie dévastatrice dans le monde entier. Pour étudier l'effet d'une température basse $\left(4^{\circ} \mathrm{C}\right)$ sur les caractéristiques biologiques et l'agressivité d'isolats des deux espèces, collectés dans le même champ à Baiyinchagan, en Mongolie intérieure, leur vitesse de croissance mycélienne, leur niveau de sécrétion d'acide oxalique et leur activité polygalacturonase ont été comparés à une température de culture normale $\left(23^{\circ} \mathrm{C}\right)$ et à basse température $\left(4^{\circ} \mathrm{C}\right)$. L'agressivité a également été évaluée sur des feuilles détachées en inoculant les isolats produits aux deux températures. Les résultats suggèrent que la culture des isolats à $4^{\circ} \mathrm{C}$ favorise non seulement la croissance mycélienne, mais augmente également la sécrétion d'acide oxalique et l'activité de la polygalacturonase des souches $S$. sclerotiorum et $S$. minor par rapport à celle de $23^{\circ} \mathrm{C}$. En outre, l'agressivité correspondante des deux espèces a également augmenté après la culture à $4{ }^{\circ} \mathrm{C}$. Cependant, S. sclerotiorum a toujours montré une croissance mycélienne plus rapide, des niveaux d'acide oxalique plus élevés et une activité polygalacturonase supérieure à celle de $\mathrm{S}$. minor à la fois à $23^{\circ} \mathrm{C}$ et à $4{ }^{\circ} \mathrm{C}$, ce qui indique que la première est généralement l'espèce la plus agressive.
\end{abstract}

Mots-clés : Sclerotinia sclerotiorum / Sclerotinia minor / culture à basse température / caractéristiques biologiques / agressivité

\section{Introduction}

Sunflower White Mold (SWM) caused by both Sclerotinia sclerotiorum and Sclerotinia minor is one of the most

*Correspondence: zhaojun@imau.edu.cn important diseases of sunflower and can cause serious yield losses (Gulya et al., 1997; Van Becelaere and Miller, 2004; Liu et al., 2018). Inner Mongolia, located in northern China is a major confectionery sunflower producing area, with a planting area around 0.86 million hectares. S. sclerotiorum and S. minor are two necrotrophic pathogens with broad host ranges and 
distributed globally, although $S$. sclerotiorum is more common than $S$. minor in most sunflower planting regions (Wu et al., 2008; Roghayeh et al., 2018). The symptoms of SWM caused by $S$. sclerotiorum and $S$. minor are different. S. sclerotiorum causes root, stem, leaf and capitulum rot at different developmental stages of sunflower (Sharma et al., 2016), whereas, $S$. minor causes only basal stem rot (Li et al., 2016b).

The infection process of SWM can be divided into two phases: biotrophic and necrotrophic phase (Kabbage et al., 2013). Following a short biotrophic phase after infection, both $S$. sclerotiorum and $S$. minor can cause tissue maceration and necrosis, leading to rapid cell death and host cell wall degradation. Toxins and cell wall degrading enzymes (CWDEs) such as polygalacturonase (PG) are believed to play critical roles in promoting these processes (Xia et al., 2020). Previously, oxalic acid (OA) was thought to be a necessary virulence factor for $S$. sclerotiorum infection, not only reducing the $\mathrm{pH}$ of host cells and enhancing the activity of CWDE, but also inhibiting the oxygen burst and selfphagocytosis, thus facilitating cell apoptosis in host plants (Godoy et al., 1990; Guimarães and Stotz 2004; Williams et al., 2011; Kabbage et al., 2013). This is also called the oxalate-dependent theory. However, some data indicated that $\mathrm{OA}$ is not a pivotal pathogenic factor, but only provides an acidic environment for pathogen infection, this is known as the $\mathrm{pH}$-dependent theory ( $\mathrm{Xu}$ et al., 2018). Apart from the pathogenicity theories mentioned above some effectors have been identified based on genomic sequence analysis, and these have been verified as functional virulence factors if the host does not contain corresponding resistance proteins (Liu et al., 2015).

The two pathogens can form sclerotia as dormant structures at late developmental stages of sunflower, but sclerotia formed by $S$. minor are much smaller than those of S. sclerotiorum (Li et al., 2016a). Environmental factors such as soil temperature and moisture can influence sclerotia formation and mycelial growth rate of both $S$. minor and S. sclerotiorum. Fernandes et al. (2016) reported that the temprature suitable for mycelium growth of both pathogens was possible between $7{ }^{\circ} \mathrm{C}$ and $27^{\circ} \mathrm{C}$, but $22^{\circ} \mathrm{C}$ is the most suitable cultural temperature and no mycelia growth at $32^{\circ} \mathrm{C}$. The specific temperature and time required for preconditioning of sclerotia to stimulate carpogenic germination vary among different studies (Clarkson et al., 2017; Dillard et al., 1995; Mila et al., 2008).

In this study, low temperature culture $\left(4^{\circ} \mathrm{C}\right)$ was found accidently to affect the development of both $S$. sclerotiorum and $S$. minor. The mycelial growth rate, oxalate secretion ability and $\mathrm{PG}$ enzyme activity were compared at $23^{\circ} \mathrm{C}$ and $4{ }^{\circ} \mathrm{C}$ using isolates of both species, which were collected from diseased sunflower plants. The aggressiveness of the isolates tested was also determined using a detached leaf inoculation method. The aim of this study was to make clear the effects of $4{ }^{\circ} \mathrm{C}$ culture on both the biological characteristics and aggressiveness of $S$. sclerotiorum and $S$. minor.

\section{Materials and methods}

\subsection{Fungal and plant material}

Sclerotia of both S. sclerotiorum and S. minor were collected from the same sunflower field in Gaojiadi,
Baiyinchagan town, Wulanchabu city, Inner Mongolia $\left(\mathrm{N} 41^{\circ} 64^{\prime} 20^{\prime \prime}\right.$, E113 $\left.13^{\prime} 01^{\prime \prime}\right)$, where located at an altitude of $1419 \mathrm{~m}$ with low temperatures in summer. The $S$. sclerotiorum isolates were labeled as S.s-2, S.s-5, S.s-10 and S. minor isolates as S.m-1, S.m-3, S.m-8.

Sclerotia collected from individual infected sunflower stems were surface-sterilized in $75 \%$ alcohol for $30 \mathrm{~s}$, then in $0.1 \% \mathrm{NaCIO}$ for $3 \mathrm{~min}$ and finally washed 3 times with distilled water. The sterilized sclerotia was then placed on potato dextrose agar (PDA) and incubated for $72 \mathrm{~h}$ at $23^{\circ} \mathrm{C}$. Pure cultures were obtained after three hyphal tip multiplications. The sclerotia formed on the edge of the purified colonies were collected and stored at $4{ }^{\circ} \mathrm{C}$ for further analysis.

The seeds of confectionery sunflower variety (LD5009) were purchased from Beijing Kaifuri Seed Industry Company.

\subsection{Cultural mediums}

Potato dextrose agar (PDA) medium was made from $200 \mathrm{~g}$ of potato, $20 \mathrm{~g}$ of dextrose, and $15 \mathrm{~g}$ of agar per liter of distilled water.

Potato dextrose broth (PDB) medium consisted of $200 \mathrm{~g}$ potato, $15 \mathrm{~g}$ dextrose per liter of distilled water.

Minimal medium(MM) media contained $1 \mathrm{~g} \mathrm{NaOH}, 3 \mathrm{~g}$ DL-malic acid, $2 \mathrm{~g} \mathrm{NH}_{4} \mathrm{NO}_{3}, 0.1 \mathrm{~g} \mathrm{MgSO}_{4} \mathrm{H}_{2} \mathrm{O}, 39 \mathrm{~g}$ Bactoagar in $1000 \mathrm{~mL}$ water, $\mathrm{pH} 4.8$ (Li et al., 2016a).

\subsection{Low-temperature processing method}

Purified S. sclerotiorum and S. minor isolates were cultured on PDA plates at $23^{\circ} \mathrm{C}$ for two days, then $5 \mathrm{~mm}$ diameter mycelial plugs were cut from the edge of the colony and transferred on to a new PDA plate. The plates were cultured at either $23^{\circ} \mathrm{C}$ (control) or $4{ }^{\circ} \mathrm{C}$ (low temperature). When the colony of the control covered $3 / 4$ of the plate, mycelial plugs of both $S$. sclerotiorum and $S$. minor cultured at $4{ }^{\circ} \mathrm{C}$ were cut from the edge of colonies to perform the following experiments.

\subsection{Determination of mycelial growth rate}

The mycelial plugs (5-mm diameter) cut from the actively growing edge of low temperature culture plate were placed on new PDA plates and cultured under normal condition $\left(23^{\circ} \mathrm{C}\right)$. The cross diameter method was used to measure and record the colony diameters of each isolate, with three replications. The average diameter recorded in the table was calculated from the diameter of the three replicates measured after culture for 3 days.

\subsection{Oxalic acid (OA) measurement}

A 5-mm diameter mycelial plug cut from the actively growing edge of a 2-day-old culture colony was inoculated into $40 \mathrm{~mL}$ of PDB and incubated in a static position at $23^{\circ} \mathrm{C}$ for 5 days. The filtrate of the cultur was used for analyzing $\mathrm{OA}$ concentration following the procedure described by Durman et al. (2005). The reaction mixture containing $0.2 \mathrm{~mL}$ filtrate (or standard oxalic acid solution), $0.11 \mathrm{~mL}$ BPB $0.1 \mathrm{~mm}$, 
$0.20 \mathrm{~mL}$ sulfuric acid $1 \mathrm{M}, 0.18 \mathrm{~mL} \mathrm{~mL}$ potassium dichromate $100 \mathrm{~mm}$ and $4.8 \mathrm{~mL} \mathrm{~mL}$ of distilled water was placed in a $60^{\circ} \mathrm{C}$ water bath for $10 \mathrm{~min}$, followed by quenching and addition of sodium hydroxide solution to the final concentration of $0.75 \mathrm{~mm}$. The absorbance was measured at $600 \mathrm{~nm}$ using a spectrophotometer (TU-1901, Beijing Purkinje General liability company, China). OA concentration was calculated based on a standard curve. The assay was performed in triplicates and each with three technical replicates.

\subsection{Polygalacturonases (PG) enzymatic assay}

A $5 \mathrm{~mm}$ diameter mycelia plug cut from actively growing edge of colony was inoculated into a flask containing $80 \mathrm{~mL}$ PDB. Cultures were shaken at $140 \mathrm{rpm}$ at $23^{\circ} \mathrm{C}$ for 10 days. After centrifuging at $5000 \mathrm{rpm}$ for $15 \mathrm{~min}$, the aqueous phase was decanted and assayed for PG enzymatic activity. The 3, 5 dinitrosalicylic acid (DNSA) assay was used to assay PG enzymatic activity (Moyo et al., 2003). A $400 \mu \mathrm{L}$ aliquot of $0.5 \%$ pectin was mixed with culture filtrate and topped up to a final volume of $500 \mu \mathrm{L}$ by adding $0.1 \mathrm{~mol} / \mathrm{L}$ sodium acetate. Samples were incubated at $30^{\circ} \mathrm{C}$ for $5 \mathrm{~h}$. DNSA reagent (44 mmol/L DNSA, $4 \mathrm{mmol} / \mathrm{L}$ sodium sulphite, $75 \mathrm{mmol} / \mathrm{L}$ $\mathrm{NaOH}$ ) was added and the samples were boiled for $10 \mathrm{~min}$ to stop the reaction. The volume of samples was adjusted to $2 \mathrm{~mL}$ by adding deionized water and the absorbance was measured at $540 \mathrm{~nm}$ using a spectrophotometer. Absorbance values were used to determine the enzymatic activity from a standard curve generated with $\mathrm{D}-(+)$ galacturonic acid. The assay was performed in triplicate and each with three technical replicates.

\subsection{Aggressiveness assessment}

When the colony diameter of control isolates covered 3/4 of the petri dish under $23^{\circ} \mathrm{C}$ culture condition, the PDA plates cultured under $4{ }^{\circ} \mathrm{C}$ were taken out of the incubator. A $5 \mathrm{~mm}$ diameter mycelia plug was cut from the edge of colony and transferred into MM medium. Aggressiveness assay was performed on detached leaves of confectionery sunflower variety LD5009. The leaves were collected from sunflower seedlings with 6 true leaves (V6 stage) and placed on a moist filter paper soaked in a covered plastic container (Length $32.5 \mathrm{~cm} \times$ width $26 \mathrm{~cm} \times$ height $11.5 \mathrm{~cm}$ ).

A $5 \mathrm{~mm}$ diameter mycelial plug was cut from the actively growing edge of 3-day-old culture on MM media and placed upside down on the abaxial side of the detached leaves. The MM plain plug (control) was inoculated on the other side of same inoculated leaf as a control. The covered plastic container containing the inoculated leaves were kept at room temperature (RT) and the lesion diameters were measured after $48 \mathrm{~h}$ post inoculation (hpi). The pathogenicity assay of each isolate was performed on five detached leaves and the average size of the lesion diameters represented the aggressiveness of each isolate.

\subsection{Data analysis}

Differences in biological characteristics and aggressiveness of cultured isolates under normal and low temperature
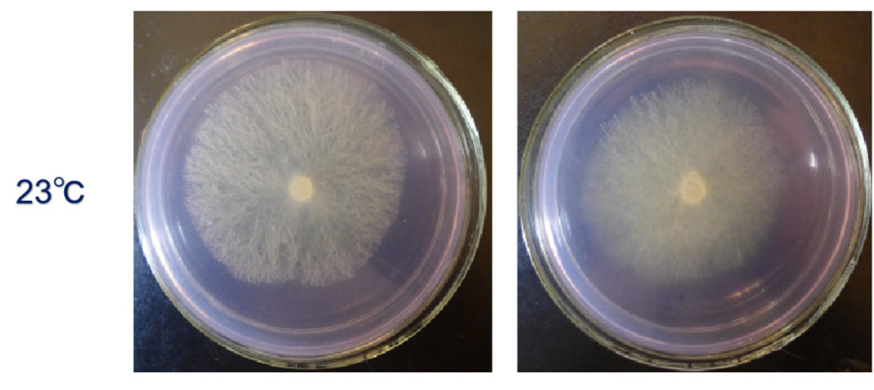

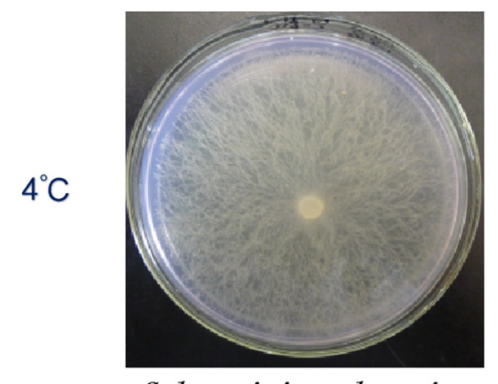

Sclerotinia sclerotiorum (S. s-2)

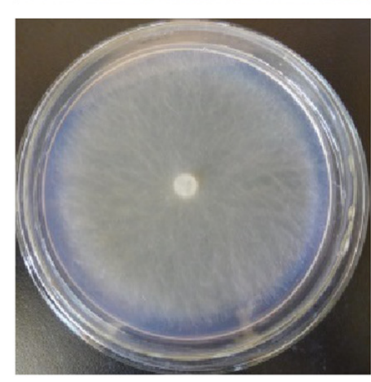

Sclerotinia minor (S. $\mathrm{m}^{-}$)
Fig. 1. The comparison on mycelial growth rate of both $S$. sclerotiorum and $S$. minor after culture under $4{ }^{\circ} \mathrm{C}$ (S.s-2 and S.m-3 representative isolates of $S$. sclerotiorum and $S$. minor.

were analyzed using SPSS 17.0 software. Duncan's new complex range method was used to test the significance of differences under 0.05 level.

\section{Results}

\subsection{Promoting mycelial growth of S. sclerotiorum and S. minor after culture at $4^{\circ} \mathrm{C}$}

The mycelia growth rate of all tested isolates cultured at $4{ }^{\circ} \mathrm{C}$ was faster than those cultured at $23{ }^{\circ} \mathrm{C}$ (Fig. 1). The average diameter of $S$. sclerotiorum and $S$. minor cultured under $23{ }^{\circ} \mathrm{C}$ for two days was $6.95 \pm 0.57 \mathrm{~cm}$ and $5.02 \pm 0.34 \mathrm{~cm}$ respectively, whereas, under same culture period at $4{ }^{\circ} \mathrm{C}$ was $8.07 \pm 0.09 \mathrm{~cm}$ and $6.69 \pm 0.23 \mathrm{~cm}$ respectively, indicating that the low temperature accelerated the mycelia growth of isolates of both species used in this study (Tab. 1). However, the average mycelia growth rate of $S$. sclerotiorum was significantly faster than that of $S$. minor under both cultural temperature conditions (Tab. 1).

\subsection{OA secretion and PG enzymes activity of S. sclerotiorum and S. minor after culture at $4{ }^{\circ} \mathrm{C}$}

The OA secretion ability of both S. sclerotorum and $S$. minor isolated was observed boosted after culture at $4{ }^{\circ} \mathrm{C}$. The average OA value of $S$. sclerotiorum and $S$. minor after $4{ }^{\circ} \mathrm{C}$ culture was $32.73 \pm 2.89 \mu \mathrm{g} / \mathrm{mL}$ and $27.32 \pm 0.21 \mu \mathrm{g} / \mathrm{mL}$, compared with $27.69 \pm 1.42 \mu \mathrm{g} / \mathrm{mL}$ and $20.63 \pm 2.25 \mu \mathrm{g} / \mathrm{mL}$ respectively at $23^{\circ} \mathrm{C}$ (Tab. 1$)$. The average OA values showed the same pattern as mycelial growth rate, higher for $S$. sclerotorum than for $S$. minor at both temperatures. 
Table 1. The average value of biological characteristics and aggressiveness of S. sclerotiorum and S. minor after culture at different temperature.

\begin{tabular}{|c|c|c|c|c|c|c|c|c|}
\hline \multirow[b]{2}{*}{$\begin{array}{l}\text { temperature } \\
\text { treatment }\end{array}$} & \multicolumn{2}{|c|}{ Growth rate / $(\mathrm{cm} \pm \mathrm{SE})$} & \multicolumn{2}{|c|}{$\begin{array}{l}\text { Oxalic acid concentration / } \\
(\mu \mathrm{g} \cdot \mathrm{mg}-1 \pm \mathrm{SE})\end{array}$} & \multicolumn{4}{|c|}{$\begin{array}{l}\text { Polygalacturonases enzymatic / Lesion diameter / }(\mathrm{cm} \pm \mathrm{SE}) \\
(\mathrm{U} \cdot \mathrm{mg}-1 \pm \mathrm{SE})\end{array}$} \\
\hline & $23^{\circ} \mathrm{C}$ & $4^{\circ} \mathrm{C}$ & $23^{\circ} \mathrm{C}$ & $4{ }^{\circ} \mathrm{C}$ & $23^{\circ} \mathrm{C}$ & $4{ }^{\circ} \mathrm{C}$ & $23^{\circ} \mathrm{C}$ & ${ }^{\circ} \mathrm{C}$ \\
\hline S. sclerotiorum & $6.95 \pm 0.57 b$ & $8.07 \pm 0.09 \mathrm{a}$ & $27.69 \pm 1.42 b$ & $32.73 \pm 2.89 a$ & $22.56 \pm 1.37 \mathrm{~b}$ & $26.37 \pm 2.62 \mathrm{a}$ & $2.57 \pm 0.27 b$ & $3.34 \pm 0.38 \mathrm{a}$ \\
\hline S. minor & $5.02 \pm 0.34 b$ & $6.69 \pm 0.23 a$ & $20.63 \pm 2.25 b$ & $27.32 \pm 0.21 \mathrm{a}$ & $21.57 \pm 0.32 b$ & $24.54 \pm 0.90 \mathrm{a}$ & $2.08 \pm 0.11 b$ & $2.43 \pm 0.14 \mathrm{a}$ \\
\hline
\end{tabular}

Table 2. The average value of biological characteristics and aggressiveness of tested isolates after culture at different temperature.

\begin{tabular}{|c|c|c|c|c|c|c|c|c|}
\hline \multirow[b]{2}{*}{$\begin{array}{l}\text { temperature } \\
\text { treatment }\end{array}$} & \multicolumn{2}{|c|}{$\begin{array}{l}\text { Growth rate / } \\
(\mathrm{cm} \pm \mathrm{SE})\end{array}$} & \multicolumn{2}{|c|}{$\begin{array}{l}\text { Oxalic acid secretion / } \\
(\mu \mathrm{g} \cdot \mathrm{mg}-1 \pm \mathrm{SE})\end{array}$} & \multicolumn{2}{|c|}{$\begin{array}{l}\text { Polygalacturonases enzymatic / } \\
(\mathrm{U} \cdot \mathrm{mg}-1 \pm \mathrm{SE})\end{array}$} & \multicolumn{2}{|c|}{$\begin{array}{l}\text { Lesion diameter / } \\
(\mathrm{cm} \pm \mathrm{SE})\end{array}$} \\
\hline & $23^{\circ} \mathrm{C}$ & $4{ }^{\circ} \mathrm{C}$ & $23^{\circ} \mathrm{C}$ & $4^{\circ} \mathrm{C}$ & $23^{\circ} \mathrm{C}$ & $4{ }^{\circ} \mathrm{C}$ & $23^{\circ} \mathrm{C}$ & $4^{\circ} \mathrm{C}$ \\
\hline S.s-2 & $6.40 \pm 0.10 \mathrm{~b}$ & $8.10 \pm 0.00 \mathrm{a}$ & $26.69 \pm 0.68 b$ & $35.84 \pm 0.96 \mathrm{a}$ & $21.46 \pm 0.54 b$ & $27.94 \pm 0.27 \mathrm{a}$ & $2.26 \pm 0.09 b$ & $3.24 \pm 0.05 \mathrm{a}$ \\
\hline S.s-5 & $6.93 \pm 0.47 \mathrm{a}$ & $7.97 \pm 0.12 \mathrm{a}$ & $27.06 \pm 1.02 \mathrm{~b}$ & $32.24 \pm 0.62 \mathrm{a}$ & $22.12 \pm 1.18 b$ & $27.82 \pm 0.91 \mathrm{a}$ & $2.72 \pm 0.08 b$ & $3.76 \pm 0.05 a$ \\
\hline S.s-10 & $7.53 \pm 0.25 \mathrm{a}$ & $8.13 \pm 0.25 a$ & $29.31 \pm 1.04 \mathrm{a}$ & $30.13 \pm 0.53 \mathrm{a}$ & $24.09 \pm 0.61 b$ & $23.35 \pm 0.55 \mathrm{a}$ & $2.72 \pm 0.04 b$ & $3.02 \pm 0.11 \mathrm{a}$ \\
\hline S.m-3 & $4.97 \pm 0.21 b$ & $6.87 \pm 0.31 \mathrm{a}$ & $23.01 \pm 0.56 b$ & $27.13 \pm 0.43 \mathrm{a}$ & $21.30 \pm 0.52 b$ & $24.62 \pm 0.77 \mathrm{a}$ & $2.10 \pm 0.07 b$ & $2.46 \pm 0.11 \mathrm{a}$ \\
\hline S.m-8 & $5.40 \pm 0.20 \mathrm{a}$ & $6.77 \pm 0.77 \mathrm{a}$ & $18.54 \pm 0.84 b$ & $27.55 \pm 1.11 \mathrm{a}$ & $21.92 \pm 0.80 \mathrm{a}$ & $25.40 \pm 1.34 \mathrm{a}$ & $1.96 \pm 0.05 b$ & $2.28 \pm 0.08 \mathrm{a}$ \\
\hline
\end{tabular}

OA levels of S. sclerotiorum isolates S.s-2 and S.s-5 increased from $26.69 \pm 0.68 \mu \mathrm{g} / \mathrm{mL}$ and $27.06 \pm 1.02 \mu \mathrm{g} / \mathrm{mL}$ at $23{ }^{\circ} \mathrm{C}$ to $35.84 \pm 0.96 \mu \mathrm{g} / \mathrm{mL}$ and $32.24 \pm 0.62 \mu \mathrm{g} / \mathrm{mL}$ respectively at $4{ }^{\circ} \mathrm{C}$. For $S$. minor isolates, the same trend was detected, with S.m-8 showing the greatest increase $(9.01 \mu \mathrm{g} / \mathrm{mL})$, followed by S.m-1 $(6.94 \mu \mathrm{g} / \mathrm{mL})$ and S.m-3 $(4.12 \mu \mathrm{g} / \mathrm{mL})$.

The average PG enzymatic activities of $S$. sclerotiorum and $S$. minor were $26.37 \mathrm{U} / \mathrm{mg}$ and $24.54 \mathrm{U} / \mathrm{mg}$ respectively after culture under $4{ }^{\circ} \mathrm{C}$, compared with $22.56 \mathrm{U} / \mathrm{mg}$ and $21.57 \mathrm{U} / \mathrm{mg}$ respectively at $23{ }^{\circ} \mathrm{C}$ (Tab. 1), with no significant difference between species.

PG enzymatic activity level of S.sclerotiorum isolates S.s-2 and S.s-5 increased from $21.46 \pm 0.54 \mathrm{U} / \mathrm{mg}$ and $22.12 \pm 1.18 \mathrm{U} / \mathrm{mg}$ at $23{ }^{\circ} \mathrm{C}$ to $27.94 \pm 0.27 \mathrm{U} / \mathrm{mg}$ and $27.82 \pm 0.91 \mathrm{U} / \mathrm{mg}$ at $4{ }^{\circ} \mathrm{C}$ (Tab. 2).

For $S$. minor, $\mathrm{PG}$ enzymatic activity of all three isolates increased significantly, especially for S.m-8, the increased value listed at the top, it is $3.48 \mathrm{U} / \mathrm{mg}$, whereas, for S.m-3 and S.m-1, the increase value is $3.32 \mathrm{U} / \mathrm{mg}$ and $2.13 \mathrm{U} / \mathrm{mg}$ respectively.

\subsection{Enhanced aggressiveness of S. sclerotiorum and S. minor post $4^{\circ} \mathrm{C}$ culture}

To assay the aggressiveness of $S$. sclerotiorum and $S$. minor after culturing at $4{ }^{\circ} \mathrm{C}$, lesion diameter on detached leaves was measured under lab condition. After 2 dpi, S.s-10 and S.s-5 cultured at $23{ }^{\circ} \mathrm{C}$ appeared more aggressive than S.s- 2 with lesion diameters of $2.72 \pm 0.08 \mathrm{~cm}, 2.72 \pm 0.04 \mathrm{~cm}$ and
$2.26 \pm 0.09 \mathrm{~cm}$ respectively. However, after culturing at $4{ }^{\circ} \mathrm{C}$, the aggressiveness of S.s-5 was enhanced with a lesion diameter of $3.76 \mathrm{~cm}$, followed by S.s-2 $(3.24 \mathrm{~cm})$ and S.s-10 $(3.02 \mathrm{~cm})$. The aggressiveness of three isolates of $S$. minor showed a minor difference after being cultured at $23{ }^{\circ} \mathrm{C}$, the leison diameter of S.m-1 is $2.18 \mathrm{~cm}$, followed by S.m-3 (2.10 $\mathrm{cm})$ and S.m-8 $(1.96 \mathrm{~cm})$. Especially for S.m-1 $(2.18 \mathrm{~cm})$, compared with S.m-3 $(2.10 \mathrm{~cm})$ and S.m-8 $(1.96 \mathrm{~cm})$. Their aggressiveness increased accordingly after being cultured at $4{ }^{\circ} \mathrm{C}$.

The average lesion diameter of $S$. sclerotiorum and $S$. minor cultured at $4{ }^{\circ} \mathrm{C}$ was $3.34 \pm 0.38 \mathrm{~cm}$ and $2.43 \pm 0.14 \mathrm{~cm}$ respectively, while it was $2.57 \pm 0.27 \mathrm{~cm}$ and $2.08 \pm 0.11 \mathrm{~cm}$ at $23^{\circ} \mathrm{C}$ (Tab. 1). The enhanced aggressiveness of $S$. sclerotiorum at $4^{\circ} \mathrm{C}$ was more significant than that of $S$. minor., the two species showed a significant difference.

\section{Conclusion and discussion}

In Inner Mongolia, both $S$. sclerotiorum and $S$. minor were isolated from diseased plants with SWM symptoms, but, $S$. minor isolates were only collected from sunflower fields which were located in the northern piedmont region of Yin mountain with high altitudes and low temperatures in summer. The lowest temperature in August is about $6{ }^{\circ} \mathrm{C}$. Sometimes, SWM infected plants caused by $S$. sclerotiorum were also observed in fields in which SWM was dominantly caused by $S$. minor, but co-infection by both $S$. sclerotiorum and $S$. minor was never encountered. Previous studies showed that mycelial growth of both $S$. sclerotiorum and $S$. minor occurred at 
temperatures ranging from $12{ }^{\circ} \mathrm{C}$ to $27^{\circ} \mathrm{C}$, and sclerotia of $S$. minor germinated and exhibited mycelial growth at temperatures ranging from $6{ }^{\circ} \mathrm{C}$ to $30^{\circ} \mathrm{C}$, but $S$. minor shows much more sensitivity to low temperature (Domingues et al., 2016). Based on the low temperatures in summer in the region where we observed SWM caused by $S$. minor, it was speculated that $S$. minor is favorised by such low temperature. Isolates of $S$. sclerotiorum collected from regions with mild temperatures do need cold "conditioning" treatment in winter to promote sclerotia germination and producing apothecium (Phillips, 1987), although germination at different temperatures varies between isolates collected from different geographic origins. This result, and the extensive distribution of $S$. sclerotiorum, suggests that this species is adapted to a much wider range of environmental conditions than $S$. minor (Young et al., 2004; Clarkson et al., 2017).

Since the northern piedmont region of Yin Mountain is the only region where $S$. minor was collected from diseased sunflower plants, this study was to determinel if low temperature could affect the biological characteristics of both S. sclerotiorum and S. minor isolated from this region and thus affect the isolate aggressiveness. Our results showed that not only mycelium growth rate increased, but also OA secretion ability and PG enzyme activity were boosted after culture at $4^{\circ} \mathrm{C}$, suggesting that aggressiveness was also enhanced accordingly. Additionally, the average value of the key pathogenic factors of S. sclerotiorum such as OA value and PG enzyme activity was much higher than that of $S$. minor, indicating that genetic differences between S. sclerotiorum and $S$. minor may cause the response differently to temperature variations. The result also provided an exaplanation why $S$. sclerotiorum is the dominant causal agent for SWM worldwide, whereas, $S$. minor is only observed in certain sunflower planting regions which have typical environmental condition (Najafzadeh et al., 2018).

In this study we also showed that low temperature treatment can significantly enhance the aggressiveness of both $S$. sclerotiorum and $S$. minor, but increased value for $S$. sclerotiorum was greater than that of $S$. minor. This agrees with earlier observation that the pathogenicity of $S$. minor isolates collected from rapeseed in the central region of China showed mild pathogenicity compared to S. sclerotiorum (Yang et al., 2016). However, the molecular mechanism underlying such kind of phenomena is still poorly understood and needs in depth investigation in the future.

Acknowledgment. This work was funded by China Agricultural Research System (CARS-14), Inner Mongolia Scientific Major Project and Inner Mongolia Academic Station for Specific Project (201803048).

\section{References}

Clarkson JP, Phelps K, Whipps JM, Young CS, Smith JA, Watling M. 2007. Forecasting Sclerotinia disease on lettuce: a predictive model for carpogenic germination of Sclerotinia sclerotiorum sclerotia. Phytopathology 97(5): 621-631.

Clarkson JP, Warmington RJ, Walley PG, et al. 2017. Population structure of Sclerotinia subarctica and Sclerotinia sclerotiorum in England, Scotland and Norway. Front Microbiol 8: 490.
Dillard HR, Ludwig JW, Hunter JE. 1995. Conditioning sclerotia of Sclerotinia sclerotiorum for carpogenic germination. Plant Dis 79 (4): 411-415.

Domingues MVPF, de Moura KE, Salomão D, Elias LM, Patricio FRA. 2016. Effect of temperature on mycelial growth of Trichoderma, Sclerotinia minor and S. sclerotiorum, as well as on mycoparasitism. Summa Phytopathol 42(3): 222-227.

Durman SB, Menendez AB, Godeas AM. 2005. Variation in oxalic acid production and mycelial compatibility within field populations of Sclerotinia sclerotiorum. Soil Biol Biochem 37(12): 2180-2184.

Fernandes DMVP, De MKE, Denise S, et al. 2016. Effect of temperature on mycelial growth of Trichoderma, Sclerotinia minor and S. sclerotiorum, as well as on mycoparasitism [J]. Summa Phytopathologica 42(3): 222-227.

Godoy G, Steadman JR, Dickman MB, Dam R. 1990. Use of mutants to demonstrate the role of oxalic acid in pathogenicity of Sclerotinia sclerotiorum on phaseolus vulgaris. Physiol Mol Plant Path 37(3): 179-191.

Guimarães RL, Stotz HU. 2004. Oxalate production by Sclerotinia sclerotiorum deregulates guard cells during infection. Plant Physiol 136(3): 3703-3711.

Gulya TM, Rashid KY, Masirevic SM. Sunflower diseases. In: Schneiter AA, ed. Sunflower technology and production. Agronomy Monograph 35. Madison (Wisconsin): ASA, CSSA, and SSSA, 1997, pp. 263-379.

Kabbage M, Williams B, Dickman MB. 2013. Cell death control: the interplay of apoptosis and autophagy in the pathogenicity of Sclerotinia sclerotiorum. PLoS Pathog 9(4): e1003287.

Li M, Zhang YY, Wang K, et al. 2016a. First report of sunflower white mold caused by Sclerotinia minor Jagger in Inner Mongolia region, China. Plant Disease 100(1): 211-211.

Li M, Jia R, Na R, et al. 2016b. Genetic diversity of Sclerotinia sclerotiorum within a single sunflower field in Wenquan, Xinjiang Province, China. J Plant Pathol, 43-53.

Liang X, Liberti D, Li M, et al. 2015. Oxaloacetate acetylhydrolase gene mutants of $\mathrm{S}$ clerotinia sclerotiorum do not accumulate oxalic acid, but do produce limited lesions on host plants. Mol Plant Pathol 16(6): 559-571.

Liu F, Wang M, Wen J, et al. 2015. Overexpression of barley oxalate oxidase gene induces partial leaf resistance to Sclerotinia sclerotiorum in transgenic oilseed rape. J Plant Pathol 64(6): 1407-1416.

Liu J, Meng Q, Zhang Y, et al. 2018. Mycelial compatibility group and genetic variation of sunflower Sclerotinia sclerotiorum in Northeast China. Physiol Mol Plant Path 102: 185-192.

Mila AL, Yang XB. 2008. Effects of fluctuating soil temperature and water potential on sclerotia germination and apothecial production of Sclerotinia sclerotiorum. Plant Dis 92: 78-82.

Moyo S, Gashe BA, Collison EK, Mpuchane S. 2003. Optimising growth conditions for the pectinolytic activity of Kluyveromyces wickerhamii by using response surface methodology. Int J Food Microbiol 85(1-2): 87-100.

Najafzadeh R, Darvishzadeh R, Musa-Khalifani K, Abrinbana M, Alipour H. 2018. Retrotransposonable regions of sunflower genome having relevance with resistance to Sclerotinia species: S. sclerotiorum and S. minor. Australas Plant Pathol 47(5): 511-519.

Phillips AJ. 1987. Carpogenic germination of sclerotia of Sclerolinia sclerotiorum: a review. Phytophylactica 19(3): 279-284.

Sharma P, Meena PD, Verma PR, et al. 2016. Sclerotinia sclerotiorum (Lib) de Bary causing Sclerotinia rot in oilseed Brassicas: a review. J Oilseeds Bras 1(2): 1-44. 
Williams B, Kabbage M, Kim HJ, Britt R, Dickman MB. 2011. Tipping the balance: Sclerotinia sclerotiorum secreted oxalic acid suppresses host defenses by manipulating the host redox environment. PLoS Pathog 7(6): e1002107.

Wu BM, Subbarao KV, Liu YB. 2008. Comparative survival of sclerotia of Sclerotinia minor and S. sclerotiorum. Phytopathology 98(6): 659-665.

Xia S, Xu Y, Hoy R, Zhang J, Qin L, Li X. 2020. The notorious soilborne pathogenic fungus sclerotinia sclerotiorum: an update on genes studied with mutant analysis. Pathogens 9(1): 27.

Xu L, Li G, Jiang D, Chen W. 2018. Sclerotinia sclerotiorum: an evaluation of virulence theories. Annu Rev Phytopathol 56: 311-338.
Yang D, Zhang J, Wu M, et al. 2016. Characterization of the Mycelial Compatibility Groups and Mating Type Alleles in Populations of Sclerotinia minor in Central China[J]. Plant Disease 100(11).

Young CS, Clarkson JP, Smith JA, Watling M, Phelps K, Whipps JM. 2004. Environmental conditions influencing Sclerotinia sclerotiorum infection and disease development in lettuce. Plant Pathol 53(4): 387-397.

Van Becelaere G, Miller JF. 2004. Combining ability for resistance to Sclerotinia head rot in sunflower. Crop Sci 44(5), $1542-1545$.

Cite this article as: Jia R, Li M, Zhang J, Addrah ME, Zhao J. 2021. Effect of low temperature culture on the biological characteristics and aggressiveness of Sclerotinia sclerotiorum and Sclerotinia minor. OCL 28: 20. 